\title{
DON'T PUT MY ARTICLE ONLINEI: EXTENDING COPYRIGHT'S NEW-USE DOGTRINE TO THE ELECTRONIC PUBLISHING MEDIA AND BEYOND
}

\section{SIDNEY A. ROSENZWEIG†}

For last year's words belong to last year's language, And next year's words await another voice. - T.S. Eliot ${ }^{1}$

\section{INTRODUCTION}

The methods by which we conduct legal research have evolved dramatically over the last decade. ${ }^{2}$ The electronic media, ${ }^{3}$ which include online services such as LEXIS and Westlaw as well as compact-disc read-only-memory devices (CD-ROMs) for computers,

† Sc.B. 1993, Brown University; J.D. Candidate 1996, University of Pennsylvania. I would like to thank Professor Ed Baker for his help, my Law Review peers, particularly Adam Cutler, Scott Goldberg, Jaimy Levine, and Hilary Siegel, for their patience, and my family for their support.

${ }^{1}$ T.S. ElIOT, Little Gidding, in FOUR QUARTETS 35, 39 (1944).

2 In beginning research for this Comment, for example, I did not use any printed newspapers and only sparingly referred to bound journals. Instead, with several quick database searches on LEXIS and Westlaw, I was able to print out the scores of articles I needed to begin this project.

"This Comment uses the term "electronic media" to refer to the new generation of media that provide alternative avenues of distribution for the content available in traditional publishing. These media, which enable electronic publishing, do not here include television or radio broadcasting. "Electronic publishing" has been defined as "the providing of traditional magazine or book-based materials with computer-aided processes," Alan J. Hartnick, Checklist for Lawyers for Multimedia Matters, N.Y. L.J., Oct. 8,1993 , at 5 , and has been analogized to the marriage between print publishing and broadcasting. See RICHARD M. NEUSTADT, THE BIRTH OF ELECTRONIC PUBLISHING 1 (1982) (noting, however, that electronic publishing poses new and unique concerns). The goal of electronic publishing is to judiciously disseminate information to a chosen audience by means of these computer-aided processes. See JOOST KIST, ELECTRONIC PUBLISHING: LOOKING FOR A BLUEPRINT 12 (Routledge 1988) (1987). Electronic publishing includes the much-hyped multimedia. See Hartnick, supra, at 5 ("Electronic publishing begins with text. Add sound and visual images, and you have multimedia."); see also Susan Orenstein, Digital Multimedia Madness, LEGAL TIMES, Sept. 13, 1993, available in LEXIS, News Library, Lgltme File (discussing online newspapers as one aspect of "multimedia"). 
have changed the ways we as a society gather information. ${ }^{4}$ Although these new media provide new methods of information distribution, they also create conflicts over the ownership of the content distributed and represent the source of publishing's "most bitter battle in years. ${ }^{n 5}$ These conflicts stem from a lack of appreciation of future technologies by parties to contracts involving the freelance writer, illustrator, or photographer who informally assigns rights to a book publisher, newspaper, or magazine. Consider, for example, the freelance journalist in 1980 who, over the customary handshake, sold a story to a local newspaper. Then, in 1985 , when the first CD-ROM system became available, the newspaper either distributed the article on CD-ROM or licensed another company to do so. How broad was the scope of the 1980 grant from the journalist to the newspaper? Did it encompass the right to exploit then-undeveloped future technologies such as GD-ROM, or did the journalist instead implicitly reserve all future technology rights?

Historically, the issue of ownership of the right to exploit a future medium was limited to the performing arts, including motion pictures, television, and videocassettes. Electronic publishing, however, has forced a careful reexamination of the rights to new uses. This reappraisal has become necessary because the content distributed in these media broadly encompasses not only all of print, but, with the consideration of multimedia applications, nearly any type or form of creative authorship. ${ }^{6}$ In the coming years, even newer media technologies will continue to present new problems in copyright licensing. ${ }^{7}$

4 See, e.g., M. ETHAN Katsh, THE Electronic MEdia AND the Transformation OF LAW 39-48 (1989) (discussing the impact of electronic media on modern life and the law); NEUSTADT, supra note 3, at 1 (observing that electronic publishing "may change the way we create, obtain and use information"); see also Note, Toward a Unified Theory of Copyright Infringement for an Advanced Technological Era, 96 HARV. L. REV. 450, 450-51 (1982) (discussing the development of comprehensive electronic journal systems); Rosalind Resnick, Writers, Data Bases Do Battle, NAT'L L.J., Mar. 7, 1994, at 1, 28 ("Now that computers and modems are cheaper and easier to use and millions of people are turning to online networks, print publishers are racing to come out with electronic editions of their books, newspapers and magazines."); Orenstein, supra note 3 (quoting Ronald Laurie, a computer law attorney, as noting that the "trend is toward putting everything into accessible databases"). B20.

${ }^{5}$ Deirdre Carmody, Writers Fight for Electronic Rights, N.Y. TIMES, Nov. 7, 1994, at

${ }^{6}$ See 17 U.S.C. $\$ 102$ (1988) (providing a nonexclusive list of categories of authorship protectable by copyright).

${ }^{7}$ See infra note 153 and accompanying text (discussing new media technologies such as global information networks and interactive television). 
This Comment examines the historical treatment of new-use assignments and proposes a simpler analysis that encourages the new uses to develop to their full potential. Part I briefly discusses the history and development of electronic media and then examines the conflicts these media have created over the distribution of content. Part II considers the methods by which courts, through nearly a century of common law, have traditionally interpreted contracts in light of new media. Part III examines the traditional common-law analysis and questions the implications of its future application, noting particularly the inconsistent results and utilitarian inefficiencies that are rooted in the existing common law. The alternative treatment proposed in Part III favors judicial interpretations that implicitly grant future technology rights on policy grounds to the producer or publisher, because that party is in the better position to exploit the new medium. Such a policy can, in effect, subsidize infant media until they become commercially viable, without reducing the incentives to authorship that are sought by the Constitution. ${ }^{8}$

Part IV applies the proposal of Part III to electronic media in light of their history, as examined in Part I, and then sets forth the conditions under which courts should interpret agreements to have granted rights to exploit works on electronic media. Part V, an epilogue to this analysis, examines the relationship between parties who today bargain for electronic media rights-rights to an existing, rather than future, technology. Additionally, this Part very briefly considers even newer media that represent the next generation of future technologies. Although the generation of new media examined throughout this Comment might no longer pose new-use issues for contracting parties today (whereas they do indeed pose problems for courts interpreting older contracts that preceded these uses), new media will always be looming, and accompanying them, the relevancy of future technology issues in copyright licensing.

${ }^{8}$ The Constitution empowers Congress to regulate copyright in order "[ $\left.t\right] 0$ promote the ... useful Arts, by securing for limited Times to Authors ... the exclusive Right to their . . . Writings ...." U.S. CONST. art. I, § 8, cl. 8. 


\section{The EleCtRonic MEDIA}

\section{A. A Historical Overview}

\section{Online Services}

Computer databases store packages of information-whether they be newspaper articles, cases, books, or photograph collections-in digital form. ${ }^{9}$ Online services, which began to develop in the late $1950 \mathrm{~s},{ }^{10}$ distribute the database information, making it available to remote terminals via telecommunications networks. ${ }^{11}$ By the mid-1960s several dozen information databases existed; ${ }^{12}$ by the mid-1970s that number had increased to nearly three hundred, ${ }^{13}$ spurred by new developments and the decreasing cost of computers. ${ }^{14}$ Full-scale electronic information services became

${ }^{9}$ For definitions and explanations of databases, see ELECTRONIC PUBLISHING- A SNAPSHOT OF THE EARLY 1980S 15-16 (Hugh Evison Look ed., 1983) [hereinafter ELECTRONIC PUBLISHING] (listing some of the different types of information that can be compiled in database form); FrAN SPIGAI \& PETER SOMMER, GuIDE TO ELECTRONIC Publishing: Opportunities in ONLINe and Viewdata Services 5-10 (1982) (surveying different database subjects and the types of information included therein).

${ }^{10}$ See, e.g., KIST, supra note 3, at 6 ("The first commercial online system was probably Quotron Systems of Los Angeles, which launched a service in 1957 that provided electronically distributed, up-to-the-minute stock market prices. The next major development [did not occur] . . . until the early 1970s-when Lockheed opened three databases.").

"See EleCtronic PUBlishing, supra note 9, at 196.

${ }^{12}$ See Tung Yin, Post-Modern Printing Presses: Extending Freedom of Press to Protect Electronic Information Services, 8 HIGH TECH. L.J. 311, 315 (1993). One early player was the Dialog service which evolved from databases created in 1963 by the Lockheed Corporation, but did not become commercially available until 1972. See KIST, supra note 3, at 145 (discussing Dialog's evolution); SPIGAI \& SOMMER, supra note 9, at 24 (noting that Dialog has since become a "large[] online reference system").

${ }^{13}$ See Yin, supra note 12, at 315; see also SPIGAI \& SOMMER, supra note 9, at 3 ('T $T$ ] he online 'industry' has existed as a commercial phenomenon only since the early 1970s."). The LEXIS legal database, for example, was created in 1973, but was not available without a proprietary terminal until 1983; the NEXIS database for the general population was not conceived until 1980. See KIST, supra note 3, at 152 (charting the evolution of LEXIS and NEXIS). The Dow Jones News/Retrieval service, the first large-scale information service, became available in 1973. See infra note 15.

${ }^{14}$ See, e.g., ELECTRONIC PUBlishinc, supra note 9, at 2 (noting that "it was not until the early 1970s that multiple-user sharing of the same computer facility became both technically and economically feasible thanks to the well-documented fact that during the 60 s and the 70s the cost of computer power dropped by around $30 \%$ per year"); see also SPIGAI \& SOMMER, supra note 9, at 3 (attributing the industry's growth to six specific computer advancements). By the mid-1970s, data networks became available that allowed users to affordably connect to information services, and newer 
widely available to the American public by $1982,{ }^{15}$ and in 1993 online services had four million subscribers. ${ }^{16}$ In 1994 , the total number of online computer service users topped 6.3 million. ${ }^{17}$ Today, the online information service industry takes in an estimated $\$ 13.4$ billion per year in revenue, ${ }^{18}$ and this robust growth is expected to continue. ${ }^{19}$ Most of the nation's major newspapers and magazines now appear in databases or online, ${ }^{20}$ and the book

modems enabled faster data transmission speeds. See id. at 2-3.

${ }^{15}$ See, e.g., NEUSTADT, supra note 3, at 20-22 (listing the starting dates of various large-scale information services, with the vast majority formed by 1982 , and some beginning as early as 1979); SPIGAI \& SOMMER, supra note 9, at 3 (calling the 1980s the "decade of the online publisher"). The only large-scale information service available in the United States before 1979 was Dow Jones News/Retrieval, which began operations in 1973. See NEUSTADT, supra note 3, at 20; cf. KIST, supra note 3, at 146 (placing the date of inception of the Dow Jones service in 1974). In 1982, despite the arrival of many information suppliers, the online industry remained small: Dialog, at the time the largest online system, had approximately 13,000 users. See SPIGAI \& SOMMER, supra note 9, at 24 (detailing the Dialog service).

${ }^{16}$ See Yin, supra note 12, at 317 (noting that this statistic "represent[s] a growth of revenue of twenty-seven percent for the industry from $1992^{n}$ ).

${ }^{17}$ See On-Line Services Reach More Than 6 Million Subscribers, Reuters Newswire, Jan. 13, 1995, available in LEXIS, News Library, Reubus File [hereinafter 6 Million Subscribers] ( ${ }^{\circ}$ On-line computer services enjoyed another boom in popularity last year, [in the United States], with the number of subscribers jumping nearly 40 percent from 1993 as competition pushed down prices ....").

${ }^{18}$ See, e.g., Geraldine Fabrikant, Times Co. Regains Control of Electronic Rights to Paper, N.Y. TIMES, Dec. 3, 1994, at 39, 41 (analyzing the value of the online market).

${ }^{19}$ See 6 Million Subscribers, supra note 17 (noting that "growth is expected to continue" as a result of "an increase in the number of personal computers that come prepackaged with at least one service as part of their software offerings").

${ }^{20}$ See, e.g., Fabrikant, supra note 18, at 41 (discussing the many ways by which the New York Times can be electronically accessed); William Glaberson, Times Company Plans Shift to More Electronic Media, N.Y. TIMES, Dec. 7, 1994, at D1, D18 (noting that the New York Times plans to increase its reliance on electronic media so that "ultimately 75 percent of [its] profits come from print and 25 percent from electronic media," and plans to invest upwards of $\$ 40$ million in the next three years to develop its electronic services); Pat Guy, Free-lance Writers Sue Electronic Publishers, USA TODAY, Dec. 20, 1993, at 8B (noting that "an interactive version of the New York Times will join the list of publications available on the America Online computer service"); Susan Hightower, Print Journalists Travel the Information Superhighway, DURHAM (N.C.) HERALd-SUN, Feb. 8, 1995, at C7 (noting that over "70 daily U.S. newspapers now have active on-line systems or have announced they soon will have" and discussing the introduction of the AP-Gannett Personalized Information service, which "enables newspapers to offer readers a personalized news-on-demand service"); Knight-Ridder and Advance Publications Announce Joint Venture, Feb. 1, 1995, available in LEXIS, News Library, US File (discussing the collaboration between newspaper conglomerates Knight-Ridder and Advance Publications to develop content for the Internet, available first on the World Wide Web); Jay Mathews, Writers Sue on Story Use by Data Services, WASH. POST., Dec. 17, 1993, at C3 ("[I]n 1992 more than 3,000 print publications, including most major newspapers and magazines, were carried on 
publishing industry ${ }^{21}$ and the Library of Congress ${ }^{22}$ plan to follow this trend.

\section{CD-ROM}

Unlike online services that give a computer user remote access to the database of an information provider, CD-ROM systems provide the user with a full copy of the information itself. ${ }^{23}$ Each

electronic databases."); Michael Putzel, A Personal Journal from Dow Jones, BOSTON GLOBE, Feb. 6, 1995, at 19 (describing the electronic version of the Wall Street Journal, called the "Personal Journal," that electronically provides a subscriber with daily news customized to her specifications).

Recently, when workers of the San Francisco Chronicle and the San Francisco Examiner went on strike, the striking employees and management each published an online newspaper in lieu of the printed versions. See Alice Z. Cuneo, San Francisco's Newspaper Strike Spurs Online Action, ADVERTISING AGE, Nov. 14, 1994, at 8 (noting that each day 25,000 readers accessed the labor newspaper, and 20,000 accessed the management newspaper); Hacks or Hackers?, ECONOMIST, Nov. 12, 1994, at 78 (observing that on its first day of operation, the union's electronic newspaper was read by 37,000 people).

${ }^{21}$ See Susan Moran, Authors Seek Higher Royalties on Electronic Rights, Reuters Eur. Bus. Rep., Apr. 11, 1994, available in LEXIS, News Library, Reueub File ("Most big publishing houses, faced with slow growth from their traditional book businesses, have mapped out plans to expand electronic publishing and distribution."); Calvin Reid, NWU Paper Addresses Online Concerns, PUBLISHERs WKLY., Oct. 10, 1994, at 8, 9 (noting that there exist at least a half-dozen online book publishers); see also Mary L. Mills, New Technology and the Limitations of Copyright Law: An Argument for Finding Alternatives to Copyright Legislation in an Era of Rapid Technological Change, 65 CHI.KENT L. REV. 307,308 n.5 (1989) (suggesting that electronic books may eventually replace printed books).

22 The Library of Congress plans to "create a vast 'virtual library' of digitized images of books, drawings, manuscripts and photographs that would look just like the originals and could be sent over computer networks to computer screens and highdefinition television sets, accessible to millions of students and researchers." Peter H. Lewis, Library of Congress Offers to Feed the Data Highway, N.Y. Times, Sept. 12, 1994, at B11; see also Olin Chism, Electronic Superlibrary in the Cards, DALLAS MORNING NEwS, Sept. 18, 1994, at J8 (discussing the current extent of online services provided by the Library of Congress).

A substantial portion of the Library of Congress's 104-million-item collection is covered by copyrights. See Lewis, supra, at B11. The digitization of any of these items presents the same dilemma as with other media. See Library of Congress Proposes Nation's Digital Library, COMMON CARRIER WK., Sept. 19, 1994, available in LEXIS, News Library, ZTL1 File (discussing copyright issues caused by digitizing copyrighted materials); Virtual National Library: Library of Congress Proposes Nation's Digital Library, COMM. DAILY, Sept. 12, 1994, at 1 (noting that the Library of Congress's project requires a "[c]omprehensive plan dealing with copyright issues"). Assuming that some royalties are paid by the Library of Congress for access to this material, the fundamental question is whether these royalties are to be paid to the publishers or to the authors.

23 See TONy Hendley, CD-ROM ANd Optical Publishing Systems 47 (1987). 
CD-ROM disc can digitally store 600 million characters of text, 250 thousand typewritten pages, or one nine-volume encyclopedia. ${ }^{24}$ Because of their large storage capacity and relatively low cost of production, ${ }^{25}$ compact discs allow computer users access to tremendous amounts of information.

Compact discs, invented in 1980, were launched commercially in 1983 to store music. ${ }^{26}$ CD-ROMs are used to store digital data accessible by computer rather than by compact-disc player, ${ }^{27}$ and were introduced commercially for this purpose in $1985 .{ }^{28}$ In 1994, the number of CD-ROM players grew to 26.9 million units worldwide. ${ }^{29}$ The number of consumer titles for CD-ROM software doubled in 1994, and is expected to double again in $1995 .^{30}$ The publishing industry has begun to take advantage of the CD-ROM medium as a complementary means for distributing its products. ${ }^{31}$ Newspapers intend to begin exploiting the CD-ROM medium as well. $^{32}$

\section{B. The Current Battle over Distribution Rights in New Media}

These new media are the battleground for freelance writers and publishers, with each group seeking the rights to use existing works on the new media. ${ }^{33}$ Although publishers ordinarily have the

The CD-ROM format may be less suitable for the newspaper and magazine industries because the data in online systems can be supplemented with little or no turnaround time, thereby maintaining the currency of the database, whereas up-to-date CD-ROMs must first be manufactured and distributed. See id.

${ }^{24}$ See Jean-Loup Tournier, Authors' Rights and New Modes of Exploitation, 16 Colum.-VLA J.L. \& ARTS 441, 442 (1992). Each disc stores 550 megabytes of information. See HENDLEY, supra note 23, at 16.

${ }^{25}$ See HENDLEY, supra note 23, at 6 (comparing CD-ROMs with other computer storage technologies); see also Steve Alexander, Computing in Las Vegas, STAR TRIB. (Minneapolis), Jan. 5, 1995, at 1D (noting that each CD-ROM costs about one dollar to manufacture).

${ }^{26}$ See HENDLEY, supra note 23 , at 12.

${ }^{27}$ See id. at 13-18 (comparing the CD-ROM and audio-compact-disc formats).

${ }^{28} \mathrm{See} i d$. at 9.

${ }^{29}$ See CD-ROM Readers Now Number 26.9 Million, Reuters, Jan. 12, 1995, available in LEXIS, News Library, Curnws File.

${ }^{30}$ See id.

31 See, e.g., Grant Buckler, Playboy Castro CD-ROM Interview Sparks "Piracy" Dispute, Newsbytes News Network, Apr. 27, 1994, available in LEXIS, News Library, Curnws File (discussing Playboy's use of CD-ROM to distribute previously published articles).

${ }^{32}$ See Glaberson, supra note 20, at D1 (explaining that the New York Times intends to develop new media, including CD-ROM). But see supra note 23 (discussing the inherent limitations of the CD-ROM format for newspapers).

${ }^{33}$ See infra text accompanying notes $41-43$ (discussing the conflict between writers 
rights to use preexisting content produced by their staff writers under the work-made-for-hire doctrine, ${ }^{34}$ the usage of works by freelancers is subject solely to interpretation of the underlying contract between the two parties. ${ }^{35}$ Historically, however, parties have been lax in creating written, ${ }^{36}$ let alone unambiguous, ${ }^{37}$ contracts. Until recently, magazines and newspapers bought articles "simply on the basis of oral agreements," ${ }^{p 8}$ and the freelance contracts that did exist did not expressly address the parties' rights in electronic media. ${ }^{39}$ Courts must decide, then, whether these agreements conveyed more than the right for the newspaper to print the work once. ${ }^{40}$

and publishers).

${ }^{34}$ See 17 U.S.C. $\$ 101$ (1988) (defining a "work made for hire" as, in part, "a work prepared by an employee within the scope of his or her employment"); MARSHALL LEAFFER, UNDERSTANDING COPYRIGHT LAW § 5.2[A]-[B] (1989) (describing the workmade-for-hire doctrine and explaining that the employer is granted all rights unless a written agreement between the employer and employee explicitly states otherwise). A work made for hire may also be "a work ... commissioned for use as a contribution to a collective work ... if the parties expressly agree in a written instrument signed by them that the work shall be considered a work made for hire." 17 U.S.C. $\S 101$. As an example of a collective work, $\$ 101$ offers "a periodical issue." Id.; see also LEAFFER, supra, § 5.2[B] (explaining that the writing conferring a made-for-hire status on a work "must be signed by both parties, and ... must consist of explicit wording that the work be considered a work made for hire").

${ }^{35}$ The contract between the parties may convey the copyright in whatever manner the parties choose. See RoberT A. Gorman, Copyright LAw 52-53 (1991) (discussing copyright assignments and licenses). Section 201(d)(1) of the Copyright Act of 1976 (1976 Act) provides that "ownership of a copyright may be transferred in whole or in part by any means of conveyance or by operation of law, and may be bequeathed by will or pass as personal property by the applicable laws of intestate succession." 17 U.S.C. \$ 201(d)(1) (1988).

${ }^{36}$ See Don E. Tomlinson \& Christopher R. Harris, Free-Lance Photojournalism in a Digital World: Copyright, Lanham Act $\mathcal{F}^{2}$ Droit Moral Considerations Plus a Sui Generis Solution, 45 FED. COMM. L.J. 1, 23 (1992) (noting that in the photojournalism trade "[c]ommitments [are] made without written purchase orders [and] obligations are fulfilled on the basis of a telephone call or handshake" (quoting CLIFTON C. EDOM, PhOTOJOURNALISM PRINCIPLES AND PRACTICE 255 (2d ed. 1980))); Douglas Steinberg, Note, Journalists' Rights to Their Own Work, 8 ART \& L. 113, 120-21 (1983) (discussing the history of oral contracting in journalism); Carmody, supra note 5, at B20 (noting that " $[\mathrm{b}]$ efore the days of electronic publishing, many magazines bought articles simply on the basis of oral contracts").

${ }^{37}$ See Resnick, supra note 4, at 28 (explaining that "many publishers still rely on old contracts with outdated language that fail to cover issues raised by the new electronic media").

${ }^{38}$ Carmody, supra note 5 , at B20.

${ }^{39}$ See id.

${ }^{40}$ Freelance contracts for journalists generally gave publishers "first North American serial rights," which granted the publication the exclusive right to publish the piece first. Id.; see also Guy, supra note 20, at $8 \mathrm{~B}$ (noting the contention of the 
The courts' first look at this issue will occur in Tasini $v$. New York Times. ${ }^{41}$ In Tasini, ten freelance writers filed a suit against five companies: The New York Times Co. and Times Mirror Co., both newspaper publishers; Time Warner, a magazine publisher; Mead Data Central, then owners of the LEXIS/NEXIS database services;

National Writers Union that the rights of freelance authors “are being infringed as their work is placed on electronic databases and CD-ROMs without their consent or [any] payment"); Hanna Liebman, National Writers Union Suit Seeks Clarification on Freelancers' Rights, MEDIAWEEK, Jan. 3, 1994, at 4 ("At issue are the rights to stories when such are not spelled out in written contracts.").

The interpretation of copyright assignments for content published as part of a collective work differs somewhat from that of other types of assignments. Section 201(c) of the 1976 Act provides:

In the absence of an express transfer of the copyright or of any rights under it, the owner of copyright in the collective work is presumed to have acquired only the privilege of reproducing and distributing the contribution as part of that particular collective work, any revision of that collective work, and any later collective work in the same series.

17 U.S.C. \$ 201(c) (1988); see also 3 MELVILle B. NIMMER \& DAVID NIMMER, NiMMER ON COPYRIGHT $\$ 10.10$ [B], at 10-87 to 10-97 (1994) (discussing $\$ 201$ (c) in the context of licenses).

On its face, the statute suggests that freelance writers and photographers for magazines and newspapers who did not sign contracts are presumed to have granted only first North American serial rights, rendering the discussion moot as to journalists and photographers, but not book authors. See infra notes 55-56 (noting that nonexclusive licenses may be granted orally). But see 3 NIMMER \& NIMMER, supra, $\$ 10.10[\mathrm{~B}] \mathrm{n} .6$ (observing that it is unclear whether the writing requirement of $\$ 201(c)$ of the 1976 Act applies to transfers effected before that law took effect on January 1, 1978). Although the issue appears to be unlitigated, it could be argued that the computer database should be viewed as a "revision of" or a "later collective work in the same series" as the original periodical. 17 U.S.C. $\$ 201$ (c). The basis for this argument is that to qualify for a separate copyright as a collective work, the electronic compilation would have to have a distinguishable, nontrivial variation from the underlying compilation (that being the printed newspaper or magazine). See, e.g., L. Batlin \& Son v. Snyder, 536 F.2d 486, 491 (2d Cir. 1976) (holding that changing the medium of a work is in itself insufficient to warrant recognition of a new copyright); Alfred Bell \& Co. v. Catalda Fine Arts, 191 F.2d 99, 102-03 (2d Cir. 1951) ('All that is needed to satisfy both the Constitution and the statute is that the 'author' contributed something more than a 'merely trivial' variation, something recognizably 'his own." (quoting Chamberlain v. Uris Sales Corp., 150 F.2d 512, 513 (2d Cir. 1945))). If the later, or electronic, collective work is not separately copyrightable from the earlier, or printed, compilation, then the electronic compilation should be considered "a revision" of the printed compilation. Cf. L. Batlin E् Son, 536 F.2d at 491; Secure Servs. Technology v. Time \& Space Processing, Inc., 722 F. Supp. 1354, 1363 (E.D. Va. 1989) (finding that the rearranging of binary digits in a computer protocol is too minimal a change to recognize as a derivative or collective work).

${ }^{11}$ 93-Civ.-8678 (S.D.N.Y. filed Dec. 16, 1993); see Martin Garbus, Who Owns Electronic Rights in the New Media?, N.Y. L.J., Dec. 23, 1994, at 1; Matthew Goldstein, New Copyright Claims Raised in Suits Against Online Providers, N.Y. L.J., Aug. 30, 1994, at 5 . 
and University Microfilms, an issuer of CD-ROMs of periodicals. ${ }^{42}$ The writers claim that their work was republished on online computer databases and CD-ROMs without their consent. ${ }^{43}$

On one side of this dispute are the freelance authors. They consider themselves to be "modernday sweatshop workers" who scrape a living with low salaries and no benefits. ${ }^{44}$ They believe that they are entitled to the rights to their works on new media, which would enable them to license the works to the original publisher, if they choose, for reissuance on the electronic media. On the other side are the publishers, who claim that they were granted the rights to use the works when those works were originally conveyed. The publishers deny that electronic rights, or any rights to use a work on a future technology or new medium, must be granted explicitly and separately. ${ }^{45}$ Despite their differences, both sides agree on one point: this issue "will have wideranging consequences for the publishing industry no matter which side prevails." 46

\section{A Century of Confused Common LAW: A Historical EXAMINATION OF NEW-USE ASSIGNMENTS}

Over the past century, courts have struggled to develop a common law to interpret, in the absence of explicit contractual provisions, copyright licensing or assignment agreements following the arrival of an unforeseen new medium of expression. ${ }^{47}$ Histori-

12 See Goldstein, supra note 41, at 5; see also Resnick, supra note 4, at 28 (noting that the Tasini plaintiffs seek damages as well); Writers Sue Publishers over Articles in Databases, WALL ST. J., Dec. 17, 1993, at B6 (stating that the Tasini plaintiffs charged copyright infringement and asked for a permanent injunction to prevent the continuance of the alleged infringement). Tasini promises to be the first suit to examine, on the merits, copyright assignments of future technologies in the traditional publishing media. A similar suit has since settled, and resulted in a payment by the publisher to the creator. See Bruce Hartford, Ensuring Cyberspace Copyrights, S.F. EXAMINER, Nov. 27, 1994, at C5; Playboy Settles with Author, NWU in E-Rights Dispute, PUBLISHER'S WKLY, July 4, 1994, at 14 [hereinafter Playboy Settles]. In that suit, a freelance author sued Playboy for distributing on CD-ROM his 1967 interview with Fidel Castro. See Buckler, supra note 31. The rights to the CD-ROM distribution were unclear because the 1967 contract preceded the advent of optical computer-disc technology. See id.; Hartford, supra, at C5.

${ }^{43}$ See Goldstein, supra note 41, at 5; Resnick, supra note 4, at 28.

${ }^{14}$ Mary Voboril, Writes and Wrongs: Freelancers Are Struggling Against Low Pay, Deadbeat Publishers and Ownership of Electric Rights, NEWSDAY (N.Y.), Feb. 21, 1994, at 23 (quoting Jonathan Tasini, president of the National Writers Union).

${ }^{45}$ See Resnick, supra note 4, at 28.

${ }^{46} I d$.

${ }^{47}$ The earliest reported cases address the interpretations of assignments of plays 
cally, these new media have included silent motion pictures, ${ }^{48}$ talking motion pictures, ${ }^{49}$ television, ${ }^{50}$ and videocassettes. ${ }^{51}$

in the wake of motion picture development. See, e.g., Manners v. Morosco, 252 U.S. 317,327 (1920) (granting an injunction against the representation of a play in moving pictures); Harper Bros. v. Klaw, 232 F. 609, 613 (S.D.N.Y. 1916) (finding an implied negative covenant that prevented both the grantor and the grantee of a copyright in a play from representing the play in motion pictures); Lipzin v. Gordin, 166 N.Y.S. 792, 792 (Sup. Ct. 1915) (holding that an exclusive license to produce a play carried with it the right to produce a motion picture as well); Frohman v. Fitch, 149 N.Y.S. 633, 634 (App. Div. 1914) (finding that a grant of rights to a play did not permit its production as a motion picture because neither party contemplated such rights when the agreement was made).

${ }^{18}$ See supra note 47.

${ }^{19}$ See, e.g., Murphy v. Warner Bros. Pictures, 112 F.2d 746, 748 (9th Cir. 1940) (holding that a transfer of motion-picture rights in a copyrighted play includes the right to produce talking motion pictures); L.C. Page \& Co.v. Fox Film Corp., 83 F.2d 196, 199 (2d Cir. 1936) (finding that exclusive moving-picture rights granted by an author in her book included the rights to produce talking motion pictures, although the latter medium was unknown at the time the agreement was executed); Macloon v. Vitagraph, Inc., 30 F.2d 634, 635 (2d Cir. 1929) (holding that the stage rights to a play include the rights to produce a motion picture of the play); G. Ricordi \& Co.v. Paramount Pictures Corp., 92 F. Supp. 537, 541 (S.D.N.Y. 1950) (holding that exclusive dramatic rights to an opera included the right of dramatization in motionpicture form); Kirke La Shelle Co. v. Paul Armstrong Co., 188 N.E. 163, 165 (N.Y. 1933) (holding that a right to profits in a play encompassed a right in the same share of profits from production of the play as a talking motion picture); Cinema Corp. of America v. De Mille, 267 N.Y.S. 327, 327 (Sup. Ct. 1933) (concluding that an author who by his own conduct had divested himself of all property in a story had also transferred talking motion picture rights, although talking motion pictures were unknown when the agreement was executed).

${ }^{50}$ See, e.g., Bartsch v. Metro-Goldwyn-Mayer, Inc., 391 F.2d 150, 155 (2d Cir. 1968) (holding that an assignment of the rights to exhibit motion pictures of a copyrighted play included the right to televise the motion picture); Ettore v. Philco Television Broadcasting Corp., 229 F.2d 481, 487 (3d Cir. 1956) (finding television stations liable for damages for broadcasting an old motion picture of a prizefight without the consent of one of the fighters); Filmvideo Releasing Corp. v. Hastings, 446 F. Supp. 725,727 (S.D.N.Y. 1978) (holding that the reservation of television rights in a transfer agreement operated to prohibit the exhibition of a motion picture on television); Landon v. Twentieth Century-Fox Film Corp., 384 F. Supp. 450, 452 (S.D.N.Y. 1974) (holding that a copyright holder's sole and exclusive grant to a film corporation to use a book included the right to broadcast the motion picture version of the book on television).

${ }^{31}$ See, e.g., Subafilms, Ltd. v. MGM-Pathe Communications Co., No. 91-56248, 1993 WL 39269, at *4 (9th Cir. Feb. 17, 1993) (finding that the uncontracted-for videotape distribution of a movie infringed the licensor's copyright), vacated in part on other grounds, 24 F.3d 1088 (9th Cir. 1994) (en banc); Rey v. Lafferty, 990 F.2d 1379,1387 (1st Cir. 1993) (holding that a grant of "television viewing" rights to 104 film episodes of Curious George did not encompass the right to distribute the films in videocassette form); ABKCO Music, Inc. v. Westminster Music, Ltd., 838 F. Supp. 153, 154 (S.D.N.Y. 1993) (concluding that it was a question for the jury whether a grant of all rights in copyrighted songs included the right to publish these songs on videocassette, a form unknown at the time the contract was written); Brown v. 
Each arrival created a new property right, namely the right to display the copyrighted work in the new medium, ${ }^{52}$ and forced courts to grapple with whether licenses for these new media were granted along with those for the preexisting media. ${ }^{53}$

Together, these cases establish a common law for contract construction that transcends the contractual language of each case. $^{54}$ A coherent common law is necessary because, without mention of future uses in the contracts themselves, ${ }^{55}$ or without written contracts at all, ${ }^{56}$ courts are confronted with fundamentally

Twentieth Century Fox Film Corp., 799 F. Supp. 166, $171-72$ (D.D.C. 1992) (holding that an agreement between a musical entertainer and a television producer that allowed the reproduction of the entertainer's performance on a television show embraced reproduction of the performance on film, videocassette, and videodisc as well); Platinum Record Co. v. Lucasfilm, Ltd., 566 F. Supp. 226, 227 (D.N.J. 1983) (holding that an agreement allowing the use of copyrighted songs in a motion picture also permitted their use on a videocassette of the motion picture because the language of the agreement included the right to use "any means or methods now or hereafter known" for reproduction); Rooney v. Columbia Pictures Indus., 538 F. Supp. 211, 228 (S.D.N.Y. 1982) (finding that a contract between an actor and a motion-picture company allowing the company to distribute and exhibit certain movies embraced the right to use these films in alternative markets such as the commercial television, pay television, and audiovisual device markets without further compensation to the actor); Tele-Pac, Inc. v. Grainger, 570 N.Y.S.2d 521, 523 (App. Div. 1991) (holding that a licensing agreement granting rights to distribute certain motion pictures "for broadcasting on television or any other similar device not known or hereafter made known" did not encompass videocassette and videodisc rights to these motion pictures).

${ }^{32}$ See, e.g., Harper Bros. v. Klaw, 232 F. 609, 613 (S.D.N.Y. 1916) (concluding that motion-picture rights "are an accretion or unearned increment conferred of late years upon the copyright owners by the ingenuity of many inventors and mechanicians").

${ }^{53}$ See 3 NIMMER \& NIMMER, supra note $40, \S 10.10$ [B], at 10-87 to 10-91 (citing new-use cases); supra notes 49-51 (same); infra part II (analyzing new-use cases).

${ }^{54}$ See 1 E. Allan Farnsworth, Farnsworth on Contracts $\$ 7.11$ (1990) (stating that rules of construction, as opposed to rules of interpretation, "help to determine the legal effect of language quite independently of the meaning that the parties may have attached to it"); Alan J. Hartnick, A Look at Grant of Rights' Provisions, N.Y. L.]., Dec. 10, 1993, at 5 (noting that "construction . . . [of a copyright license] goes beyond the written agreement").

${ }^{55}$ Although exclusive licenses must be in writing, there "is no prescribed form for the writing transferring copyright except that it be signed by the copyright owner." LEAFFER, supra note $34, \S 5.11$ [A]. As a result of the informality allowed, new-use issues are often unaddressed in the contract. See id. $\$ 5.10$ (noting that sometimes "parties fail to take into account a new medium").

${ }^{56}$ Under the 1976 Act, nonexclusive licenses need not be in writing. See 17 U.S.C. $\S \S 101,204(\mathrm{a})$; see also LEAFFER, supra note 34, \$ 5.11[A] (noting that "nonexclusive licenses ... may be transferred orally"). The publishing industry is particularly notorious for its aversion to written contracts. See supra note 36 (discussing the history of oral and informal contracting practices of publishers).

Throughout this Comment, new-use rights are discussed as belonging either to the creator-licensor or the publisher-licensee. Although such language describes 
similar questions independent of individual contracts. With the exception of several early cases, ${ }^{57}$ courts have taken a generally consistent approach to this process of contract interpretation. ${ }^{58}$ Courts will first attempt to gauge the parties' intents; if unable to assess those intents, courts will examine substantive and procedural unconscionability. If the agreement is not unconscionable in either manner, courts will determine whether the medium was relatively foreseeable. If the medium is foreseeable, the grantee is entitled to use of the new medium; if not foreseeable, the right is vested in the grantor. In order to provide a better understanding of the historical construction of these agreements, the remainder of this Part will scrutinize the steps that courts typically follow in each phase of the analysis. ${ }^{59}$

exclusive assignments per se, it also applies to the nonexclusive licenses likely to be inferred from oral contracts. In either case the issue is whether the plaintiff-creator conveyed certain new-use rights to the defendant-licensee. The economic preferability of nonexclusive licenses (in which both the licensor and the licensee could exploit the new use) to exclusive licenses (which grant rights solely to the licensee) is an empirical issue beyond the scope of this Comment. Because all case law to date has involved disputed exclusive licenses, that terminology is used throughout this Comment.

${ }^{57}$ The first courts considering the issue often enjoined both parties, the authorlicensor and producer-licensee, from taking advantage of the new medium of motion pictures. See Manners v. Morosco, 252 U.S. 317, 327 (1920); Harper Bros. v. Klaw, 232 F. 609, 613 (S.D.N.Y. 1916). Rather than granting rights to the new medium to one or both of the parties, courts required the parties to bargain for the new rights. See id. at 613 ( ${ }^{4}[\mathrm{~A}]$ s long as the contract . . . exists, neither party thereto can produce a photo-play of Ben Hur except by bargain with the other.").

Since then, courts have adopted the policy of favoring, rather than frustrating, transitions into new media by vesting ownership of the new use in one party. See Bartsch v. Metro-Goldwyn-Mayer, Inc., 391 F.2d 150, 155 (2d Cir. 1968) (stating a preference for granting the licensee the rights to the new use rather than "risk ... a deadlock between the grantor and grantee [that] might prevent the work's being shown over the new medium at all"); Macloon v. Vitagraph, Inc., 30 F.2d 634, 636 (2d Cir. 1929) ("The law always favors the free and unrestricted use of property, and doubts and ambiguities should be resolved in favor of the natural right to such free use and enjoyment, and against restrictions thereof.").

${ }^{58}$ Although some commentators recognize that the case law as a whole is not fully cohesive, see, e.g., Neil R. Nagano, Comment, Past Copyright Licenses and the New Video Software Medium, 29 UCLA L. REv. 1160, 1176 (1982) (asserting that the "application of contract construction rationales has been a superficial and tenuous one"), variations in treatment by the courts can be traced to the perceived differences between the new and old media and to the stage of development of the new medium at the time of contract. At times, however, these distinctions can be "superficial and tenuous." Id.; see also infra notes 87-89 and accompanying text (examining courts' inconsistent comparisons of new media with old).

${ }^{39}$ This step-by-step framework will explore the factors important to courts considering new-use issues. See Rey v. Lafferty, 990 F.2d 1379, 1387-88 (1st Cir. 


\section{A. The Search for Intent Is Usually in Vain}

The most, and perhaps only, straightforward way to infer intent is to examine the explicit terms of the contract itself. Short of an assignment granting all rights to a work, ${ }^{60}$ the implementation of a future technology clause, which specifies that the grantee reserves rights to use all future media, is the only way to guarantee the intended transfer of rights. ${ }^{61}$ Yet, given that parties do not know at the time of contract what types of new uses will develop, interpretive problems will ensue unless the grantor divests herself of all new uses. $^{62}$ The nature of new uses, however, generally defies an

1993); see also 3 NIMMER \& NIMMER, supra note $40, \S 10.10[\mathrm{~B}]$, at $10-91$ to $10-95$ (describing the approaches taken by courts in analyzing the uses to which a license applies); Nagano, supra note 58, at 1163-83 (analyzing past approaches to the new-use cases).

${ }^{60}$ See, e.g., Brown v. Twentieth Century Fox Film Corp., 799 F. Supp. 166, 169 (D.D.C. 1992) (noting that the agreement at issue granted rights of reproduction, exhibition, and transmission "in and by all media and means whatsoever" (quoting the agreement between the parties)); Platinum Record Co. v. Lucasfilm, Ltd., 566 F. Supp. 226, 227 (D.N.J. 1983) (noting that the parties licensed the rights "to exhibit, exploit, market and perform [American Graffiti] perpetually throughout the world by any means or methods now or hereafter known" (alteration in original) (quoting the agreement between the parties)).

${ }^{61}$ Parties' courses of conduct following the closing of the contract may also shed light on those parties' intent. See, e.g., Platinum Record Co., 566 F. Supp. at 227 (finding that, because the grantor "has registered no objections in the past to the repeated showing of American Graffiti on cable and over-the-air television," he cannot claim that the granted rights extended only to theatrical exhibitions); Filmvideo Releasing Corp. v. Hastings, 446 F. Supp. 725, 728-29 (S.D.N.Y. 1978) (suggesting that the licensee's effort to obtain television rights estopped him from claiming that he already possessed those rights). Such courses of conduct, however, are not dispositive. See Ettore v. Philco Television Broadcasting Corp., 229 F.2d 481, 483 n.4 (3d Cir. 1956) (taking notice of the licensor's initial failure to deny that he had granted television rights in conjunction with the motion picture rights granted, but looking beyond that intent to unconscionability).

62 These issues will frequently arise because, even if the parties recognize that unknown future technologies may exist, grantors may be reluctant to grant all new uses not knowing what they are giving up. Likewise, grantees may not wish to pay more for speculative new uses for which they, for a number of reasons, may not be able to exploit fully. Accordingly, parties may prefer to draw analogies between preexisting uses and new uses or to define distinctions between different types of new uses. In either case, interpretive difficulties will ensue.

In such a scenario, for example, a contract might state that the grantee may use the work by means of "television and by any other technological, mechanical or electronic means, method or device now known or hereafter conceived or created." Subafilms, Ltd. v. MGM-Pathe Communications Co., No. 91-56248, 1993 WL 39269, at *4 (9th Cir. Feb. 17, 1993) (quoting the "future technology" clause of the copyright agreement between the parties), vacated in part on other grounds, $24 \mathrm{~F} .3 \mathrm{~d} 1088$ (9th Cir. 1994) (en banc). The question then arises as to whether videocassette rights are 
examination of intent. ${ }^{63}$ Because new uses naturally arise after the assignment, and because of the length of time that can transpire between the initial assignment and the infringement on the new medium, intent regarding the assignment of rights in the medium not yet created will seldom, if ever, be found. ${ }^{64}$

\section{B. The Emergence of New Uses May Render the Original Contract Unconscionable}

Once a determination of intent is found insufficient for resolving whether a grantor has granted rights involving the new medium, a court next considers issues of unconscionability. Substantive unconscionability, as opposed to procedural unconscionability, ${ }^{65}$ examines whether the contract, on its face, is unfair to

included within television rights. See id. This raises the same issue, therefore, as when no future technology clause exists, as courts attempt to squeeze the new medium within the definition of the old. See infra text accompanying notes 78-84 (discussing the approach of analyzing the ambiguous penumbra of contractual terms).

${ }^{63}$ See Rey, 990 F.2d at 1387 ("Such absence of specific intent typifies cases which address 'new uses' of licensed materials ... . "); 3 NIMMER \& NIMMER, supra note 40, $\S 10.10$ [B], at $10-91$ (noting that searching for the parties' intent is problematic because in all likelihood "there simply was no intent at all at the time of execution with respect to this issue insofar as it relates to whether the grant includes a new use developed at a later time").

64 See 3 NIMMER \& NIMMER, supra note $40, \S 10.10[\mathrm{~B}]$, at 10-91 to 10-92 ("The very fact that we are most often dealing with a later developed technological process (even if it were known of in some form at the time of execution) suggests that the parties' ambiguous phraseology masks an absence of intent rather than a hidden intent which the court simply must 'find." "); see also Bartsch v. Metro-Goldwyn-Mayer Inc., 391 F.2d 150,155 (2d Cir. 1968) ("With Bartsch dead, his grantors apparently so, and the Warner Brothers lawyer understandably having no recollection of the negotiation, any effort to reconstruct what the parties actually intended nearly forty years ago is doomed to failure.").

${ }^{65}$ Procedural unconscionability arises from gross differences in the sophistication between the parties to contract, see 1 FARNSWORTH, supra note $54, \S 4.28$, at 506-08 (explaining that although adhesion is generally not enough to trigger the doctrine of procedural unconscionability, sometimes the deceptiveness of the contractual language and procedures used to secure the contract, as well as the inequality of bargaining power between two parties, may be enough to find unconscionability), such as between a prizefighter and a television network. In Norman v. Century Athletic Club, Inc., 69 A.2d 466 (Md. 1949), the court applied an unusually narrow definition of the word "broadcast," allowing the plaintiff-boxer to retain television, but not radio, rights. See id. at 468 . Ettore v. Philco Television Broadcasting Corp., 229 F.2d 481 (3d Cir. 1956), dealt with a prizefighter who licensed his film rights to his bout with Joe Louis. See id. at 483. NBC later broadcast the film on its television series Greatest Fights of the Century. See id. The boxer's initial reaction, evidencing his lack of sophistication, was not of dismay over the infringing use, but of dissatisfaction with the way in which the film was edited for television. See id. Looking for an analogous context, the court acknowledged that a seller of land could not, years later, 
either party. ${ }^{66}$ If the court determines that one interpretation of the contract would render it unconscionable, the court interprets the contract to avoid such an unconscionable construction. ${ }^{67}$ In the new-use setting, this doctrine is used when a new medium supplants, rather than supplements, the old one. ${ }^{68}$ Substantive unconscionability has been applied, even if not by name, ${ }^{69}$ in cases involving the transition from plays to motion pictures ${ }^{70}$ and from silent motion pictures to talking motion pictures. ${ }^{\text {"1 }}$ For this reason

following a successful housing development, rescind the contract of sale or ask for additional compensation. See id. at 488 . The court, however, ignored its analogy and justified its decision to vest the television rights in the boxer on the grounds of "fairness." Id. at 490. Courts have not found procedural unconscionability in the bargaining relationships between authors and publishers, or between playwrights and studios.

${ }^{66}$ See 1 FARNSWORTH, supra note $54, \S 4.28$, at 506 (defining substantive unconscionability as the inclusion of contract terms that are unreasonably favorable to one party).

${ }^{6} \mathrm{See}$, e.g., Ettore, 229 F.2d at 490-91 (interpreting the agreement between the parties as fairness requires); see also infra notes 70-71 (providing examples of substantive unconscionability).

${ }^{68}$ See Frohman v. Fitch, 149 N.Y.S. 633, 634 (App. Div. 1914) ("That by the aid of science it has, since the contract was executed, been made possible to produce the play in some manner not then contemplated, does not give [the grantor or the grantor's estate] the right to destroy [the grantee's] property. . . ."); see also Kirke La Shelle Co. v. Paul Armstrong Co., 188 N.E. 163, 167-68 (N.Y. 1933) (discussing Frohman).

${ }^{69}$ See, e.g., Kirke La Shelle Co., 188 N.E. at 167 (implying substantive unconscionability in the similar doctrine of good faith and fair dealing).

${ }^{70}$ See, e.g., Harper Bros. v. Klaw, 232 F. 609, 613 (S.D.N.Y. 1916) (holding that the licensor could not exploit the new motion-picture medium to the "detriment, if not destruction, of the licensees' estate"); see also Kirke La Shelle Co., 188 N.E. at 167 (preventing one party from "destroying or injuring the right of the other party to receive the fruits of the contract").

${ }^{71}$ See L.C. Page \& Co. v. Fox Film Corp., 83 F.2d 196, 199 (2d Cir. 1936) (finding that "talkies' ... are employed by the same theaters [and] enjoyed by the same audiences").

The court in Rey v. Lafferty, 990 F.2d 1379 (1st Cir. 1993), provided an illuminating analysis of the substantive unconscionability issue:

The problem [with contract interpretation] becomes particularly acute when the analogous [new] technology develops so rapidly as to supplant the originally contemplated application of the licensed work, rendering the parties' original bargain obsolete. Thus, for example, broad grants of "motion picture rights," made before technological advances permitted the combination of moving images with sound, later were held, typically, to encompass the rights to sound motion picture technology; a narrower holding would have left the original license virtually worthless, despite its broad language, and would have provided the licensor with an undeserved windfall.

Id. at $1388-89$ n.7. 
color television rights are inferred from preexisting black-and-white rights, ${ }^{72}$ and videodisc rights are likely to be inferred from videocassette rights.

\section{Foreseeing the New Technology: The Courts' Yardstick for Faimess}

If intent cannot be surmised, and there is no unconscionability, courts look to equitable policy grounds to determine whether it would be fair to grant the new-use rights to the licensee along with the preexisting rights. ${ }^{73}$ In determining whether the new technology falls within the scope of the explicitly granted or preexisting technology, courts examine the foreseeability of the new medium. ${ }^{74}$ If the technology was wholly unforeseeable-if the new medium had not yet been invented-rights are retained by the grantor. ${ }^{75}$ But if the technology was invented, though not commercialized, the rights are granted along with those for the preexisting medium. ${ }^{76}$ This boundary between the foreseeable and the unforeseeable is a guiding principle for modern courts. ${ }^{77}$

72 Judging from the lack of case law contesting the new use of color television, it is reasonable to infer that existing television rights must have undisputedly encompassed future color rights.

${ }^{73}$ See Rey, $990 \mathrm{~F} .2 \mathrm{~d}$ at 1388 (describing methods of interpretation and their underlying policy rationales).

74 Compare Bartsch v. Metro-Goldwyn-Mayer, Inc., 391 F.2d 150, 154 (2d Cir. 1968) (reading the grant at issue to include television rights because at the time of the contract between the parties in 1930, "the future possibilities of television were recognized by knowledgeable people in the entertainment and motion picture industries") with Cohen v. Paramount Pictures Corp., 845 F.2d 851, 854 (9th Cir. 1988) (refusing to enlarge the grant in the parties' contract to include videocassette distribution rights because "VCRs for home use were not invented or known in 1969, when the license was executed").

${ }^{75}$ See, e.g., Cohen, 845 F.2d at 854 (precluding the implied grant of new uses "that had not been introduced to the domestic market at the time the parties entered into the agreement ${ }^{n}$ ).

${ }^{76}$ See, e.g., Bartsch, 391 F.2d at 154 (distinguishing the case at hand from those in which the new medium had not been invented, and hence was "completely unknown at the time when the contract was written").

77 See, e.g., Rey, 990 F.2d at 1388 (recognizing different interpretive methods depending on whether the medium had been invented at the time of the grant); ABKCO Music, Inc. v. Westminster Music, Ltd., 838 F. Supp. 153, 156-57 (S.D.N.Y. 1993) (holding that under New York law, different policies are followed depending on whether the parties "could not know of the invention's existence" or instead failed to foresee the medium's potential (quoting Bartsch, 391 F.2d at 154)). 


\section{The Bartsch Approach: Contracts Granting Rights to} Use Technologies Already Created, but Not Widely

Commercialized, at the Time of the Contract

The first method, labeled as preferred by Nimmer, ${ }^{78}$ and embraced by Judge Friendly in Bartsch $v$. Metro-Goldwyn-Mayer, Inc. ${ }^{79}$ holds that "the licensee may properly pursue any uses which may reasonably be said to fall within the medium as described in the license. ${ }^{\text {80 }}$ The Bartsch court noted that this right includes uses within the "ambiguous penumbra" of the terms of the contract. ${ }^{81}$ "In other words, the question before [a] court is not whether [the licensee] gave the words the right meaning, but whether or not the words authorized the meaning he [now] gives them. ${ }^{82}$ Accordingly, a court applying the Bartsch approach would determine, for example, whether television rights fall within the motion picture rights explicitly granted, ${ }^{83}$ or whether videocassette rights similarly fall within television rights. ${ }^{84}$ Although the Bartsch court granted

${ }^{78}$ See 3 NIMMER \& NIMMER, supra note 40, § 10.10[B], at 10-92 to 10-93 (noting that this alternative "is believed to be preferred ... in part because the courts are equipped to determine the outer limits of the reasonable meaning of a term . . . [and] because it is less likely to prove unjust").

79391 F.2d 150 (2d Cir. 1968).

${ }^{80} \mathrm{Id}$. at 155 (quoting Melville B. NIMMER, THE LAW OF COPYRIGHT § 125.3 (1964)).

${ }^{81}$ Id. (quoting NIMMER, supra note 80, $\$ 125.3$ ).

823 NIMMER \& NIMMER, supra note $40, \S 10.10$ [B], at 10-93 (citation omitted).

${ }^{83}$ See, e.g., Bartsch, $391 \mathrm{~F} .2 \mathrm{~d}$ at 153 (examining whether "a broad assignment of the right 'to . . . license and exhibit . . . motion picture photoplays . . .' includes the right to 'license' a broadcaster to 'exhibit' the copyrighted motion picture by a telecast without a further grant by the copyright owner" (quoting the contract between the parties)); Landon v. Twentieth Century-Fox Film Corp., 384 F. Supp. 450, 455 (S.D.N.Y. 1974) (mem.) ("[O]ne does not have to roam far into the penumbral meanings of 'motion picture versions' to conclude that the term was intended by the parties to embrace rather than exclude the right to produce a television series.").

${ }^{84}$ See, e.g., Rey v. Lafferty, 990 F.2d 1379, 1390 (1st Cir. 1993) (holding that television rights did not encompass videocassette distribution rights); Subafilms, $L t d$. v. MGM-Pathe Communications Co., No. 91-56248, 1993 WL 39269, at *4 (9th Cir. Feb. 17, 1993) (finding that a future technology clause did not encompass the home video market), vacated in part on other grounds, 24 F.3d 1088 (9th Cir. 1994) (en banc); Cohen v. Paramount Pictures Corp., 845 F.2d 851, 854 (9th Cir. 1988) (holding that television rights did not include rights to distribution of videocassettes for home viewing); Platinum Record Co. v. Lucasfilm, Ltd., 566 F. Supp. 226, 227 (D.N.J. 1983) (finding that the "absence of any specific mention" of videocassette rights is "insignificant" in the determination of foreseeability); Tele-Pac, Inc. v. Grainger, 570 N.Y.S.2d 521, 525 (App. Div. 1991) (finding television rights and videocassette rights "so dissimilar" as to preclude the conclusion that they both fall within the agreement at issue). 
rights to new uses when the parties "had reason to know of the new medium's potential," ${ }^{85}$ some courts subsequently have relaxed the level of foreseeability required for licensees to receive a grant of new-use rights. ${ }^{86}$

The weakness of this analysis is that it enables courts to play with the definitions of each medium and manipulate the comparison. For example, courts have reached different conclusions as to whether television is analogous to cinematography ${ }^{87}$ and as to whether videocassettes are analogous to television. ${ }^{88}$ These

${ }^{85}$ Bartsch, 391 F.2d at 154. The foreseeability of the new medium in Bartsch was used to distinguish the facts of that case from those of Kirke La Shelle Co. v. Paul Armstrong Co., 188 N.E. 163, 165 (N.Y. 1933), in which the parties disagreed as to whether the assignment conferred rights to the not-yet-invented medium of talking motion pictures. See Bartsch, 391 F.2d at 154.

${ }^{86}$ See, e.g., Rey, $990 \mathrm{~F} .2 \mathrm{~d}$ at 1388 (noting that a relaxed standard allows "the courts [to] presume that at least the possibility of nonspecific 'new uses' was foreseeable by the contracting parties at the time the licensing agreement was drafted"); ABKCO Music, Inc. v. Westminster Music, Ltd., 838 F. Supp. 153, 157 (S.D.N.Y. 1993) (granting videocassette rights to the licensee from the 1966 contract, despite the fact that videocassettes were not invented until the early 1970 s, because the parties to the contract were sophisticated). When the foreseeability requirement is stretched to allow nonspecific foreseeability (as in Rey) or constructive foreseeability (as in $A B K C O)$, the distinction between the foreseeable and the unforeseeable becomes arbitrary. See infra text accompanying notes 98-99 (explaining the nonsensical nature of such a distinction).

${ }^{87}$ Although they both ultimately reached the same result, the district and appellate courts in Bartsch disagreed on whether television is sufficiently analogous to cinematography. The district court found such an analogy:

The processes of theatre and home television exhibition are markedly similar.... The process of 'unscrambling' or 'descanning' the airwave transmission so as to cast the image on the television screen is quite similar to that which takes place on the theatre screen, except that on the set in the home an electronic shutter, rather than a mechanical shutter, is used to control the picture image.

Bartsch v. Metro-Goldwyn-Mayer, Inc., 270 F. Supp. 896, 900-01 (S.D.N.Y. 1967). The court of appeals, however, saw it differently:

[T]o characterize the . . miraculous processes whereby these images actuate airwaves so as to cause electronic changes in sets in millions of homes which are then 'unscrambled' or 'descanned' and thus produce pictures on television screens-along with the simultaneous electronic transmission of sound-as 'analogous' to cinematography pushes the analogy beyond the breaking point.

Bartsch, 391 F.2d at 153.

${ }^{88}$ Compare Rooney v. Columbia Pictures Indus., 538 F. Supp. 211, 228 (S.D.N.Y. 1982) (" $[T]$ here is little basis for [a] distinction between immediate exhibition of the film by television and the sale of videocassettes for home exhibition. . . . [W] hether the exhibition apparatus is a home videocassette player or a television station's broadcast transmitter, the films are 'exhibited' as images on home television screens.") with Cohen v. Paramount Pictures Corp., 845 F.2d 851, 854 (9th Cir. 1988) 
inconsistencies are to be expected because of the complexity of the comparison: an observer might regard either the projection technology or the means of distributing the work as the salient characteristic for comparison. Most courts, however, have compared the distribution methods of the two media to determine foreseeability. ${ }^{89}$

Bartsch's strength is that it encourages the use of new media by expanding the definition of the originally licensed medium to include those new media within its vague linguistic penumbra. ${ }^{90}$ The Bartsch court explicitly acknowledged this underlying policy, noting that an expansive reading of the terms of the contract

provides a single person who can make the copyrighted work available to the public over the penumbral medium, whereas [a] narrower [interpretation of the words of the contract] involves the risk that a deadlock between the grantor and the grantee might prevent the work's being shown over the new medium at all. ${ }^{91}$

Because new media are designed to improve the quality or facilitate the flow of information in society, efforts to encourage their development are in the public interest. ${ }^{92}$

("Television and videocassette display . . . have very little in common besides the fact that a conventional monitor of a television set may be used both to receive television signals and to exhibit a videocassette.").

${ }^{89}$ See Cohen, 845 F.2d at 853 (concluding that the grant of television rights "contemplates some sort of broadcasting or centralized distribution, not distribution by sale or rental of individual copies to the general public"); see also Manners v. Morosco, 252 U.S. 317, 326-27 (1920) (distinguishing motion pictures from plays on the basis of their means of distribution); Ettore v. Philco Television Broadcasting Corp., 229 F.2d 481, 488 (1956) (finding that broadcasting, "the interposition of electrical impulses which carry the picture to receiving sets," is a factor that distinguishes motion pictures from television); Tele-Pac, Inc. v. Grainger, 570 N.Y.S.2d 521, 524 (App. Div. 1991) (quoting Cohen). But see Norman v. Century Athletic Club, 69 A.2d 466, 470 (Md. 1949) (defining "broadcast" rights as including rights to transmit via radio, but not via television).

It should also be noted that if the manner of distribution is not affected by the new medium, it is likely that the new, and presumably improved, technology will supplant the old technology, triggering an unconscionability analysis. See supra notes 66-72 and accompanying text.

${ }^{90}$ See LEAFFER, supra note $34, \S 5.10$ ("[T] he broader definition supports diffusion of copyrighted works, allowing the person in the best position to distribute the work in the new media to do so.").

${ }^{91}$ Bartsch, $391 \mathrm{~F} .2 \mathrm{~d}$ at 155.

${ }^{92}$ See infra note 105 and accompanying text (discussing the prevailing belief that increased public access to information distributed on new media benefits society). 


\section{The Cohen Approach: Contracts Retaining Rights to Future}

Technologies Not Yet Created at the Time of the Contract

When the new medium does not exist at all at the time of contract, courts have been unwilling to grant licensees the windfall of the rights to use the work in the new medium. ${ }^{93}$ This approach, first adopted by New York's highest court in Kirke La Shelle Co. v. Paul Armstrong Co., ${ }^{94}$ and later followed by the Ninth Circuit in Cohen v. Paramount Pictures Corp., ${ }^{95}$ is based on an equitable concern that although it may be reasonable to hold the grantor to the court's interpretation of the language of the contract when the new medium was foreseeable, it is not fair to do so when the medium was "completely unforeseeable and therefore could not possibly have formed part of the bargain between the parties at the time of the original grant." 96

Although this distinction is meant to "prevent licensees from 'reap[ing] the entire windfall' associated with the new medium, ${ }^{n 97}$ it is grounded in fundamentally flawed logic. First, new-use issues arise precisely because parties did not contemplate future technologies and therefore formed no intent with respect to them. ${ }^{98}$ It is therefore nonsensical to use one analysis where the technology was possibly foreseeable, and another where it was unforeseeable,

${ }^{93}$ See, e.g., Cohen, 845 F.2d at 854 (asserting that the "holder of the license should not now 'reap the entire windfall' associated with the new medium" (citation omitted)); Bourne Co. v. Walt Disney Co., 1992 WL 170686, at *6 (S.D.N.Y. July 1, 1992) ("Under New York law, if the disputed use [by the licensee] was not invented when the parties signed their agreement, that use is not permitted under the contract"), rev'd on other grounds, 976 F.2d 99 (2d Cir. 1992); see also Nagano, supra note 58, at 1185 (calling for "judicial balancing of the parties' equities" to resolve and allocate "potential windfall benefits").

r 188 N.E. 163 (N.Y. 1933).

${ }^{95} 845$ F.2d 851 (9th Cir. 1988).

${ }^{96}$ Rey v. Lafferty, 990 F.2d 1379, 1388 (1st Cir. 1993) (emphasis omitted); see also Cohen, $845 \mathrm{~F} .2 \mathrm{~d}$ at 854 (noting that the licensee could not have bargained for rights of videocassette reproduction before the invention of the videocassette recorder); Kirke La Shelle Co., 188 N.E. at 165-66 (finding that the rights to make a motion picture with sound were not transferred by the agreement because the "talkie" technology to make motion pictures with sound was not yet invented at the time of the contract).

${ }^{97} R_{e y,}, 990 \mathrm{~F} .2 \mathrm{~d}$ at 1388 (alteration in original) (quoting Cohen, $845 \mathrm{~F} .2 \mathrm{~d}$ at 854).

${ }^{98}$ See, e.g., ABKCO Music, Inc. v. Westminster Music, Ltd., 838 F. Supp. 153, 156 (S.D.N.Y. 1993) (applying this contractual construction based on foreseeability "[w] here such general intent cannot be discerned from the language of the contract"); see also supra notes 63-64 and accompanying text (discussing the difficulty of determining intent in new-use cases). 
because the parties did not actually foresee the new technology in either case. ${ }^{99}$ This line between the possibly foreseeable and unforeseeable could be drawn at the time when the medium was in testing stages, in research or development, or-just as easily and arbitrarily-when the medium was just an idea in its creator's mind. In each of these cases, the technology existed in some sense, but did not play a role in formulating the contracting parties' intents. ${ }^{100}$ Second, if the parties never possess an expectation as to the allocation of future technologies-which is necessarily true because in new-use cases no intentions exist-allocating the windfall to one party does not deprive the other party of its expectations. Because the author's expectations are not frustrated, it therefore does not seem unjust to grant new-use rights broadly to licensees. ${ }^{101}$

\section{COMPARING BARTSCH AND COHEN: BROADER GRANTS OF NEW-USE RIGHTS PROVE EFFICIENT}

Policy issues strongly favor Bartsch's broad grants to new uses and future technologies. From a utilitarian standpoint, vesting ownership in publishers and other licensees rather than in creators results in smaller transaction costs and facilitates the wider dissemination of information necessary for the development of new media. Furthermore, such a policy does not contravene the purpose of the Copyright Act of $1976^{102}(1976 \mathrm{Act})$ and does not work as a disincentive to authorship.

${ }^{99}$ But see Rey, 990 F.2d at $1387-88$ (distinguishing between cases in which the new medium had not been invented at the time of contract and those in which it had been invented but had not yet been commercialized).

${ }^{100} \mathrm{~A}$ uniform rule would create more predictable results, of course, by avoiding this bifurcated treatment and generally rewarding one party-whether it be the creator or the licensee-with rights to new uses whenever those uses were not actually within the parties' contemplation. See infra text accompanying notes 125-26 (proposing a uniform treatment).

${ }^{101}$ See John H. Barton, The Economic Basis of Damages for Breach of Contract, in THE ECONOMICS OF CONTRACT LAW 154, 154 (Anthony T. Kronman \& Richard A. Posner eds., 1979) (stating that the goal of most common law courts is to protect each party's expectations); infra notes 118-24 and accompanying text (arguing that new-use policy does not affect authorial incentives).

${ }^{102}$ Copyright Act of 1976, Pub. L. No. 94-553, 90 Stat. 2541 (1976) (codified as amended at 17 U.S.C. $\S \S 101-1010$ (1988 \& Supp. V 1993)). 


\section{A. Efficiency and Transaction Costs}

As William Landes and Richard Posner have observed, "copyright law can be explained as a means for promoting [an] efficient allocation of resources." 103 Contract interpretation, too, should maximize utility. ${ }^{104}$ It is widely accepted that the proper allocation of resources with regard to electronic media is one that promotes the public's wider access to the information, thereby enhancing the public welfare. ${ }^{105}$ Therefore, windfalls should be allocated to the party that either incurs the lower transaction costs in utilizing the work in a new medium ${ }^{106}$ or is in the better posi-

103 William M. Landes \& Richard A. Posner, An Economic Analysis of Copyright Law, 18 J. LEGAL STUd. 325, 325 (1989). But see Frank P. Darr, Testing an Economic Theory of Copyright: Historical Materials and Fair Use, 32 B.C. L. REv. 1027, 1048 (1991) (recommending that courts look beyond economics and consider the ethical concerns of copyright infringement); Wendy J. Gordon, On Owning Information: Intellectual Property and the Restitutionary Impulse, 78 VA. L. REv. 149, 166-67 (1992) (suggesting that infringement invokes a human impulse against unjust enrichment).

104 See A. MrTChell POLINSKY, AN INTROduction to LAW AND ECONOMics 25 (1983) (noting that courts are expected to fill in the gaps of contracts because parties cannot negotiate and draft contracts providing for every conceivable contingency, and arguing that when courts interpret contracts, they should do so according to efficiency criteria); Anthony T. Kronman \& Richard A. Posner, Introduction: Economic Theory and Contract Law, in THE ECONOMICS OF CONTRACT LAW, supra note 101, at 5 (stating that "the law of contracts has an implicit economic logic-the purpose . . . [being] to increase economic efficiency").

${ }^{105}$ See, e.g., Sony Corp. of Am. v. Universal City Studios, Inc., 464 U.S. 417, 429 (1984) (recognizing "society's . . . interest in the free flow of ideas, information, and commerce" ); INFORMATION INFRASTRUCTURE TASK FORCE, U.S. DEP'T OF COMMERCE, Preliminary DRAFT OF THE REPORT OF THE WORKING GROUP ON INTELLEGTUAL PROPERTY RIGHTS § IV(5) (July 1994) ("The Copyright Act exists for the benefit of the public. To fulfill its constitutional purpose, the law should strive to make the information contained in protected works of authorship freely available." ); Jack B. Hicks, Copyright and Computer Databases: Is Traditional Compilation Law Adequate?, 37 COPYRIGHT L. SYMP. (ASCAP) 85, 123 (1990) ("Increased public access to information contained in automated databases is a major goal of national information policy.").

${ }^{106}$ The Coase Theorem states that to optimize efficiency when transaction costs exist, legal rules must seek to minimize those transaction costs. See R.H. Coase, The Problem of Social Cost, 3 J.L. \& ECON. 1, 16 (1960); see also POLINSKY, supra note 104, at 13-15 (discussing the Coase Theorem).

An alternative to vesting rights in the better exploiter would be to award the new uses to the party less able to anticipate the technological development; one would thereby encourage the party in the better position to acquire such information to do so. Although it would seem that publishers would be in the best position to anticipate new technologies, such a presumption is at best speculative. See I.T. Hardy, An Economic Understanding of Copyright Law's Work-Made-for-Hire Doctrine, 12 CoLuM.VLA J.L. \& ARTS 181, 194 (1988) (noting that "the cheaper-estimator rationale for resolving disputes over unforeseen uses of works is not borne out either by analysis or by an examination of the cases"). Guessing which party might have had the better 
tion to exploit the new medium itself. ${ }^{107}$

The Bartsch approach reduces the transaction costs imposed on producers of existing media by channeling existing content into new media. Rewarding authors with the rights to new uses would impose higher transaction costs because producers or publishers would have to bargain with creators to use works over new media. ${ }^{108}$

This policy has been applied convincingly in a broader context. Landes and Posner use the utilitarian model to justify providing a monopoly over derivative works to the owner of the underlying copyrighted work. ${ }^{109}$ They conclude:

Transaction costs would be reduced if one person owned both [the original work's and the derivative work's] copyrights. Of course, even if they were separately owned to begin with, one of the owners could buy the other's copyright. But this transaction, with its attendant costs, can be avoided if the law places the power to obtain both copyrights in the same person to begin with-and that is, in effect, what the law does. ${ }^{110}$

Landes and Posner, considering existing uses, examine why a single party is presumed to own all rights to derivative works without considering the implications of licensing. In the new-use context, the issue is not whether an unlicensed party infringed the author's copyright by creating a derivative work, but whether it is beneficial to

access to information would also result in vesting rights to new uses in the party least able to exploit the new medium, which is directly contrary to public policy. See id. at 193-95 (arguing that this type of concern precludes courts from employing the betterexploiter rationale, which is more efficient); supra note 105 and accompanying text (noting that public policy seeks to maximize public access to new media).

${ }^{107}$ See infra notes 112-16 and accompanying text.

${ }^{108}$ See Kronman \& Posner, supra note 104, at 6 n.6 (noting that one source of high transaction costs is the existence of a large number of parties). This transaction cost problem is particularly evident in the newspaper and magazine publishing industry. Because producers own the copyrights to employees' work under the work-made-forhire doctrine, see supra note 34 , if producers were granted the copyrights to freelancers' works, there would be no additional transaction costs for the industry at all. On the other hand, if freelancers' copyrights were vested in the creators, an entire structure of licensing would have to exist before the new medium itself commercially existed or became feasible. Although future creators might retain rights that would require this licensing structure, the general avoidance of transaction costs in the short-term subsidizes the development of new technologies. See infra text accompanying notes $125-25$.

${ }^{109}$ See Landes \& Posner, supra note 103, at 354-55. A derivative work is one that is adapted from a previous work. See 17 U.S.C. $\$ 101$ (1988). As such, derivative works encompass new uses.

${ }^{110} \mathrm{Id}$. at 355 . 
infer that the licensee, based on certain derivative rights she owns, may exploit certain additional derivative rights-namely, new uses.

Furthermore, vesting rights to new technologies in creators will seldom be in the public interest because the existing media producers are likely in a better position to exploit or develop new media with smaller transaction costs. ${ }^{111}$ Just as a movie producer is more capable than the creator of providing available content for videocassettes, ${ }^{112}$ a newspaper is in a better position than an author to promote online information services efficiently. ${ }^{113}$ In the mass-media industry, this synergy is particularly evident because of the concentration of media power. ${ }^{114}$

In the work-made-for-hire context, ${ }^{115}$ courts traditionally have

${ }^{111}$ See supra text accompanying notes 90-91, 105 (discussing the benefits of encouraging the development of new media).

112 See Landes \& Posner, supra note 103, at 356 n.40 (finding that from an economic standpoint the producers of a movie should be entitled to videocassette rights because they are better able to exploit derivative uses of the movie).

113 Cohen imposes transaction costs on the parties because it requires additional contracting in order to apply the work to a new medium. The Cohen approach also creates the risk that authors will be unwilling to license work for new media. Furthermore, the author might choose to license the work to another producer, resulting in a loss of the synergy that exists (because of the efficiency produced by economies of scale, among other reasons) when a single grantee is able to display the same work over multiple media.

114 See BEN H. BAGDikian, The MEDIA MONOPOLY at ix-x (4th ed. 1992) (noting that control of the major media is consolidated in the hands of 11 corporations, and that these firms extend their reach to many different media).

115 The comparison between work-made-for-hire cases and new-use cases is important because the issues confronted in the former parallel those found in the latter. See David H. Horowitz, Film Creators and Producers vis-a-vis the New Media: Reflections on the State of Authors' Rights in Audio Visual Works, 13 CoLUM.-VLA J.L. \& ARTS 157, 175 (1989) (stating that the work-made-for-hire doctrine provides "the right to exploit the film-without payment of additional compensation-by means and in media unknown and uncontemplated at the time of the original employment"). In both scenarios the issue is whether the party that contracted for the work was granted ownership of the copyright for unforeseen uses. Comparisons must be made, however, to the work-made-for-hire doctrine established before the 1976 Act because that act required for the first time that work-made-for-hire arrangements be stated explicitly in the contract. See 17 U.S.C. \$ 201(b) (1988); Hardy, supra note 106, at 218 \& $\mathrm{n} .82$ (noting that the 1976 Act awards copyrights to a commissioning party only in very limited circumstances, one of which being that the parties must have agreed beforehand in writing that the work is to be considered a work for hire). In new-use cases, there is no requirement that grants be placed in the contracts expressly. But see supra note 40 (discussing the potential presumption in favor of granting only first serial rights for collective works). Nonetheless, even after the 1976 Act required an express written statement to allow employers to claim that work was made for hire, many courts disregarded this explicit congressional mandate and still followed the better-exploiter rationale. See Hardy, supra note 106, at 219-20 (examining three federal appeals court cases decided after the 1976 Act that followed the better- 
rewarded employers with new-use windfalls because of their superior ability to exploit the new medium. ${ }^{116}$ As a result, "courts [have] claimed ... to apply a presumption that both parties intended the hiring party to own the copyright."117 This policy, adopted by Bartsch, should also apply when courts assign new-use rights, unless such a policy would discourage the process of authorship.

\section{B. Authorial Incentives Are Not Diminished by Interpreting Contracts to Grant New-Use Rights}

The 1976 Act's intention of granting rights to authors "to afford greater encouragement to the production of literary works of lasting benefit to the world"118 is not undermined by Bartsch's broad interpretation of new-use assignments. The granting of copyrights is designed to "advance the public welfare through the talents of authors."119 The Act, however, is not intended to provide the maximum incentives possible. ${ }^{120}$ The Bartsch approach favors the development and use of new media without diminishing an author's

exploiter rule). Although the Supreme Court later interpreted the 1976 Act to concretely require a written instrument to confer work-made-for-hire status on works prepared by independent contractors, see Community for Creative Non-Violence v. Reid, 490 U.S. 730, 753 (1989), the earlier case law and scholarly analyses shed light on contractual interpretations where no such writing requirement is presumed to exist.

${ }^{116}$ See Hardy, supra note 106, at 182 (noting that the Second and Seventh Circuits led the way in "expand[ing] the concept of 'employment' broadly enough to give copyright ownership to the party better able to exploit the work"). From a normative standpoint, Hardy agrees, arguing:

Copyright ownership should go to the party in the better position to exploit the value of the disputed work by bringing it to the public's attention. ... [This party is the one] with the greater resources, experience or better market position-the one who could, in short, more cheaply distribute the work to the public.

Id. at 181 .

${ }^{117} I d$.

${ }^{118}$ Washingtonian Publishing Co. v. Pearson, 306 U.S. 30, 36 (1939) (quoting Act of March 3, 1891, ch. 565, 26 Stat. 1106); see also Cohen v. Paramount Pictures Corp., 845 F.2d 851, 854 (9th Cir. 1988) (stating that the granting of rights to unforeseen new uses would frustrate the purposes of the 1976 Act).

${ }^{119}$ Mazer v. Stein, 347 U.S. 201, 219 (1954).

${ }^{120}$ See Sony Corp. of Am. v. Universal City Studios, Inc., 464 U.S. 417, 429 (1984) ("The monopoly privileges that Congress may authorize are neither unlimited nor primarily designed to provide a special private benefit. Rather, the limited grant is a means by which an important public purpose may be achieved."); United States v. Paramount Pictures, Inc., 334 U.S. 131, 158 (1948) ("The copyright law, like the patent statutes, makes reward to the owner a secondary consideration."). 
incentives.

A new use is "an accretion or unearned increment"121-a "windfall"122-that occurs after the production of a work. The new-use doctrine is based on the premise that the future medium was beyond the intentions of the parties; the author, as a result, could not have expected to profit from such future medium. ${ }^{123}$ The Bartsch approach, as employed in cases in which the new use was already invented at the time of the contract, does not provide a disincentive to authors because it does not frustrate expectations. In fact, there is no reason to constrain its application to those cases involving such possibly foreseeable technologies. ${ }^{124}$

In cases in which a medium was not yet invented, which require the application of Cohen, there is even less risk of defeating creators' expectations or of diminishing incentives because the technology at issue likely was even further from the parties' contemplation. Furthermore, because future parties are free to bargain as to new uses, judicial decisions vesting the usage of unspecified future technologies in the licensee do not create disincentives to future authors.

\section{A Better System: Interpreting Contracts to Grant New-Use Rights Broadly}

For the dual reasons of transaction costs and authorial incentives discussed above, this Comment proposes that grants be interpreted broadly, following Bartsch, in all circumstances in which the contract is silent, the parties' intents cannot be gauged, and no

${ }^{121}$ Harper Bros. v. Klaw, 232 F. 609, 613 (S.D.N.Y. 1916).

122 Cohen, 845 F.2d at 854 (quoting Nagano, supra note 58, at 1184).

${ }^{123}$ See supra text accompanying note 101 (discussing parties' expectations). In situations in which nonexclusive licenses may be found to exist, as with oral contracts, see supra note 56, authors will still benefit from new uses because nonexclusive licenses would allow both parties to exploit the new medium. In the case in which a nonexclusive license has been created, the author is worse off than if no license were found to exist because the new-use rights are diluted between two or more parties. Nonetheless, in such circumstances the creator is given some reward beyond her expectation of none at all.

Even if the freelance author relinquishes her new-use rights, she may reclaim them 35 years later. See 17 U.S.C. \$203(a)(3) (describing the means by which licensors may unilaterally terminate transfers and licenses). Because of the existence of this termination process, authors are deprived of new-use rights for only a fraction of the term of the copyright.

${ }^{124}$ See supra text accompanying notes 98-101 (arguing that the foreseeability of the new use should not determine who receives the windfall). 
unconscionability is present. This approach would be applied regardless of whether the medium existed when the parties contracted as long as the medium was not commercialized or otherwise rendered foreseeable at the time of the contract.

The one-time windfall from a new use, in effect, is used to subsidize the licensee in her effort-to develop the new medium ${ }^{125}$ rather than to enrich the grantor beyond her expectations. This subsidy is particularly well suited for infant media, whose economic feasibility may be uncertain until enough content is available therein to bolster consumer demand. The subsidies would apply only to ambiguous contracts that predated the medium; as the medium develops and becomes viable, it ceases to be considered a new use, and the subsidy, appropriately, discontinues. This policy spares new media with uncertain futures from cumbersome licensing procedures until the media become commercially available. Clearly, as a matter of policy, it is better to develop a new medium, ${ }^{126}$ allowing the licensee to retain any rights that reasonably can be said to flow from the contract, than to reward an author with remuneration beyond her expectations at the expense of the public interest. ${ }^{127}$

\section{The New-Use Doctrine Appled to Electronic MediA}

Following the analysis described in Part II, courts should look first for intent or unconscionability when assigning new-use rights for online systems and CD-ROMs. Assuming that neither can be found, which is likely in the absence of contracts containing future

125 See supra text accompanying notes 108-09 (explaining how such a subsidy would reduce transaction costs).

${ }^{126}$ See Bartsch, $391 \mathrm{~F} .2 \mathrm{~d}$ at 155 (preferring to grant rights to the new use to the licensee rather than to "risk ... a deadlock between the grantor and grantee [that] might prevent the work's being shown over the new medium at all"); Macloon v. Vitagraph, Inc., 30 F.2d 634, 636 (2d Cir. 1929) ("The law always favors the free and unrestricted use of property, and doubts and ambiguities should be resolved in favor of the natural right to such free use and enjoyment, and against restrictions thereof.").

${ }^{127}$ But see Nagano, supra note 58, at $1184-85$ (recommending a wide usage of the narrow Cohen rule, conferring the benefits of the new use to the licensor, and suggesting that such a policy would enable both parties to "share in the benefits of the new use"). Although this policy certainly enables the licensor to share the benefits, it does not provide any benefit to the licensee. The licensee is forced to pay to use the work in the new medium as if there were no preexisting contract at all. The "windfall" described by Nagano is the right to sell the work for use on the new medium, a right provided exclusively, under this analysis, to the grantor. See id. at 1184; see also Hardy, supra note 106, at 190-91 ("[I]t is equally true that were creators to retain the rights to these unforeseen uses, they would reap the windfall."). 
technology provisions, the policy issues surrounding the fairness of vesting rights in a particular party should be considered. ${ }^{128}$ Such a reliance on policy is particularly necessary in the publishing community because contracts in that industry tend to be unsophisticated. ${ }^{129}$

When interpreting contracts that precede the development of electronic media, courts traditionally apply the Cohen approach and vest rights in the grantor. ${ }^{130}$ Therefore, a court first needs to consider the date of development of the new media. It is difficult to determine exactly when online services were actually created; the period of development of computer databases extended from the late-1950s until the mid-1970s. ${ }^{131}$ This aspect of Cohen is a major drawback: a concrete date must be established, even though the advent of online systems occurred over several decades. But, because online systems were not developed in a manner such that they had commercial potential until about 1973, that year should be used to mark the beginning of modern online systems. ${ }^{132}$ The date of development of the CD-ROM, in contrast, is much clearer because optical technologies were invented in $1980 .{ }^{133}$ Therefore, for contracts that preceded these dates, rights to the electronic uses presumably would vest in the grantor.

For contracts entered into after these dates, the Bartsch approach would conventionally be applied. ${ }^{134}$ Bartsch grants rights

${ }^{128}$ See supra text accompanying notes 73-77.

${ }^{129}$ See supra notes $36-39$ and accompanying text.

${ }^{130}$ See supra part II.C.2 (describing the Cohen approach); see also, e.g., Rey v. Lafferty, 990 F.2d 1379, 1388 (1st Cir. 1993) (noting that the approach in Cohen may 'be appropriate where a particular 'new use' was completely unforeseeable and therefore could not possibly have formed part of the bargain between the parties at the time of the original grant"); Bourne Co. v. Walt Disney Co., 1992 WL 170686, at *6 (S.D.N.Y. July 1, 1992) ("In Bartsch, the Second Circuit confined its holding to cases where the disputed new use ... existed at the time the parties signed their agreement. It expressly distinguished situations where the new use was totally unknown at the time the parties entered into their contract."), rev'd on other grounds, 976 F.2d 99 (2d Cir. 1992).

131 See supra notes 10-14 and accompanying text (tracing the early history of online systems).

132 See supra note 15 (pinpointing the development of the Dow Jones News/ Retrieval Service, the first large-scale online information system, as occurring in 1973 or 1974).

133 See supra text accompanying note 26.

${ }^{134}$ See supra text accompanying notes $85-86$ (describing when to use the Bartsch approach); see also Rey, 990 F.2d at 1388 (noting that under such circumstances "the courts will presume that at least the possibility of nonspecific 'new uses' was foreseeable by the contracting parties at the time the contract was drafted"); Bartsch, 
to the new media to the licensee if the new media do not fall within the ambiguous penumbral definitions of the existing media rights granted or expressly retained. ${ }^{135}$ Ordinarily, Bartsch distinguishes the new media based on the method of distribution. ${ }^{136}$ Online systems, distributed by telecommunications networks, bear no resemblance to the traditional distribution of newspapers, magazines, and books. Accordingly, online systems would not fall within any preestablished penumbra from printed periodical sales, and the rights thereto might well be considered to have been retained. CDROM systems, however, share more in common with traditional distribution schemes in that they are bought and sold as discrete products. But CD-ROMs are still distinguishable from preexisting media in their means of distribution because they are not yet typically purchased at newsstands or bookstores and are distributed after the print publication. ${ }^{137}$ As a result, CD-ROM products also might not be considered to have fallen within the scope of the grant. A court might then conclude that the new-use rights were retained by the licensor. Such a resolution, however, overlooks the importance of efficiency concerns.

Although neither medium falls squarely within the scope of the grant, they do not fall precisely outside of that grant either. Without a detailed written contract there can be no references to existing rights from which penumbral definitions can be extracted. As a result, in this type of case, there exists a true "windfall," a bundle of rights that neither party forcefully can argue to own. Courts addressing this issue should adopt Bartsch's reasoning and grant the new-use rights to the licensee, the "single person who can make the copyrighted work available to the public over the penumbral medium." ${ }^{n 38}$ Therefore, the future technology rights

391 F.2d at 154 (distinguishing between not "know[ing] . . . of the [new medium's] existence" and not "know[ing] of the new medium's potential").

${ }^{155}$ See supra notes 81-84 and accompanying text; see also 3 NIMMER \& NIMMER, supra note $40, \S 10.10[\mathrm{~B}]$, at $10-93$ (finding the Bartsch approach to be preferable "because the courts are equipped to determine the outer limits of the reasonable meaning of a term when it may well be impossible to locate a supposed true and single intent of the parties that generally never in fact existed").

${ }_{136}$ See supra note 89 and accompanying text.

${ }^{137}$ See supra note 23 (discussing the inherent problems with creating timely CDROMs). Books, if distributed on CD-ROM in a manner similar to that of the print version, arguably fall within the penumbral range of the grant.

${ }^{138}$ Bartsch, 391 F.2d at 155; see also supra text accompanying notes 90-91 (discussing the Bartsch approach's encouragement of expanding the scope of the grant to include new uses). 
for contracts signed in this interim period between a medium's invention and its commercialization should belong to licensees.

Once a medium becomes clearly recognizable through its commercialization and ceases to be new, however, it might be presumed that authors reserved their rights in the absence of an explicit grant. ${ }^{139}$ The online industry, for example, began to flourish in $1982 .{ }^{140}$ CD-ROMs were commercially introduced in 1985 and achieved success more quickly than online systems. ${ }^{141}$ Accordingly, 1985 represents the last year for which CD-ROM rights might be presumed to have been granted.

The bifurcated treatment provided by Bartsch and Cohen produces an anomalous result: Whereas authors who contracted before a medium's advent would be vested with new-use rights (as might those who contracted after its commercialization), only those who bargained during this intermediate period would be considered to have granted electronic rights to the licensee. By ignoring the arbitrary foreseeability distinction of Cohen and Bartsch, however, courts would be spared the difficulty of determining exactly when a medium was no longer inchoate, allowing for a more uniform treatment. ${ }^{142}$ In addition, this proposal avoids vesting rights in one class of creators (those who contracted before the medium's advent) but not in another (those in the intermediate period who contracted after the advent but before the commercialization of the new medium), despite the fact that the creators possessed the same intentions, or lack thereof, with respect to their licenses. ${ }^{143}$ As a result, this more consistent analysis presumes that all grantors before a medium's commercialization date have granted their electronic rights to the licensee.

This treatment provides a subsidy to those publishers trying to make content available over new media during the formative years of electronic media development. Before new media become established, authors do not expect additional compensation for their works. ${ }^{144}$ To reward the authors with a windfall is to deprive

${ }^{139}$ See supra note 40 (describing the 1976 Act's presumption of limited grants as to existing uses). This Comment takes no position regarding contract interpretation for existing uses and only points out that such uses are likely to vest in the grantor.

${ }^{140}$ See supra note 15 and accompanying text.

${ }^{141}$ See supra notes 28-29 and accompanying text.

142 See supra notes $131-32$ and accompanying text.

14s See supra text accompanying notes $97-100$ (discussing how the foreseeability test often ignores the intentions of the grantor of the license).

${ }^{144}$ See supra part III.B (arguing that authors' incentives are not undermined by 
society of efficient information distribution. ${ }^{145}$

This Comment does not suggest that contracts after a medium's commercialization always be interpreted to have granted rights to electronic media. By the 1990s these electronic media were no longer in their infancy-they were present rather than future technologies-and another analysis, beyond the scope of this Comment, should be used to gauge the parties' intents at such a stage. By this time, parties might possess certain expectations regarding electronic media rights, and courts should examine the bargaining process to determine which rights were licensed in the absence of explicit provisions.

\section{Epilogue: Changes IN BARgAining for EleCTRONIC MEDIA RIGHTS}

The bargaining favored by the $1976 \mathrm{Act}^{146}$ has already begun to occur between publishers and journalists for the rights not only to the new-but-existing technologies of online systems and $\mathrm{CD}$ ROM, but also to future technologies. Since Tasini $v$. New York Times $^{147}$ rose to national prominence in December 1993, the publishing industry has begun explicitly to address future technology issues. ${ }^{148}$ Book publishers, for example, have put new contracts on the bargaining table that define the percentage of royalties from electronic uses to which authors are entitled. ${ }^{149}$ Although some

broadly granting new-use rights).

${ }^{145}$ See supra note 105 and accompanying text (discussing the policies favoring wider public access to information).

146 See H.R. REP. NO. 1476, 94th Cong., 2d Sess. 132 (1976) ("Nothing in the bill derogates from the rights of parties to contract with each other and to sue for breaches of contract .... ."); Ramona L. Paetzold, Comment, Contracts Enlarging a Copyright Owner's Rights: A Framework for Determining Unenforceability, 68 NEB. L. REV. 816,817 (1989) ("[T]he copyright system views freedom of contract as beneficial to the purposes and goals of the copyright market itself.").

${ }_{147}$ 93-Civ.-8678 (S.D.N.Y. filed Dec. 16, 1993); see supra text accompanying notes 41-43 (discussing the Tasini case).

${ }_{148}$ See, e.g., James A. Martin, Computers Make It Easy to Steal, S.F. ExAMINER, Apr. 17,1994 , at $\mathrm{Cl}$ (discussing the legal implications of the increased vulnerability of copyrighted materials because of technology advances).

${ }^{149}$ See, e.g., id. at $\mathrm{Cl}$ (describing Random House's contract in which authors receive between $10 \%$ and $16 \%$ of sales of paperback or hardcover books, but only $5 \%$ of revenues from sales from electronic publishing); Moran, supra note 21 (discussing Random House's new standard contract between authors and publishers, "setting a flat five percent royalty on electronic versions of authors' works and retaining all future publishing rights"); Calvin Reid, Authors, Agents Pan New Random Media Rights Contract, PUBLISHERS WKLY., Apr. 18, 1994, at 11 (discussing reaction of publishing industry to Random House's new standard contract). 
authors have described the new contracts as "brazen"150 or as "contracts from hell," gaining process has only begun. ${ }^{152}$

When the courts announce their views on the new-use doctrine and electronic publishing, there will no longer be an issue of futuretechnology clauses and electronic media. The one-time windfall of electronic media either will have been used to subsidize the nascent electronic media industry or will have been granted to authors to use as they wish. But this resolution will only suffice until the next new technology arrives, ${ }^{153}$ when courts will be confronted with interpreting the contracts that are now being written.

\section{CONCLUSION}

The electronic media have profoundly and permanently changed the conventional means by which information is distributed. These changes have created a new bundle of rights whose ownership is uncertain. Even in contracts drafted with great care it is difficult to determine whether new-use rights are meant to have been trans-

150 Reid, supra note 149, at 11 (quoting the Authors Guild).

151 Carmody, supra note 5, at B20.

152 See id. (stating that "[w]riters who complain ... . are often able to have huge chunks [of the contract] thrown out the window," and "[w]riters whom magazines "really need have been successful in throwing the whole contract out of the window" (quoting Dan Carlinsky, chair of contracts for the American Society of Journalists and Authors)); see also Dana Blankenhorn, Writers Sue for Online Copyright, Newsbytes News Network, Dec. 20, 1993, available in LEXIS, News Library, Curnws File (noting that in the past "some freelance writers have succeeded . . . in keeping their copyrights").

155 See, e.g., MARCLA L. DE SONNE, ADVANCED BROADCAST/MEDIA TECHNOLOGIES: MaRket Developments and Impacts in the '90S AND BeYOND 83-102 (1992) (discussing new media technologies); Jeannine Aversa, U.S. Plan for Global Information Network, S.F. CHRON., Feb. 16, 1995, at A7 (discussing the Clinton administration's plan "for a worldwide network that could let people exchange vast amounts of information as cheaply and as easily as sending a fax"); Joanne Kelly, FCC Paves Way for New Nationwide Radio Service, Reuter Bus. Rep., Jan. 12, 1995, available in LEXIS, News Library, Reubus File (noting that the FCC has "set aside space on the airwaves for a new [digital] coast-to-coast radio service that would beam compact disc quality sound to tiny satellite dishes in cars and homes across the country"); Neil Winton, Interactive TV Tempts Viewers with Computer Power, Reuter Bus. Rep., Feb. 19, 1995, available in LEXIS, News Library, Reubus File (noting that interactive television will turn viewers into "hyperactive foragers for entertainment and news" able to "direct their own movies, offering the choice of various story lines as the plot unfolds"); Patricia Zengerle, Media Giant Launches Cable Network of Future, Reuter Bus. Rep., Dec. 14, 1994, available in LEXIS, News Library, Reubus File (describing "the Full Service Network," Time Warner's "new interactive cable-TV network" that provides "[m]ovies . . . available on demand . . . almost instantly" that can be rewound, fastforwarded, or paused by the subscriber). 
ferred or retained, unless all rights are granted. New-use rights cannot be defined with precision at the time of contract because by definition they do not exist until some point after the agreement has been consummated. This problem is only exacerbated in the publishing industry where crude agreements, which until recently had been sufficient, are prevalent, if not the norm.

New-use rights are unlike other types of contractual rights because they do not form any part of the intent between contracting parties. As a result, they represent a windfall such that neither party has a greater claim to those rights. Since the early part of the century, courts have struggled to allocate these rights; the courts' approaches together establish a dividing line for when rights are presumed to have been granted and retained. The common-law boundary has established that, although rights are retained when the contract precedes the invention of the medium or possibly when it follows the medium's widespread commercialization, those rights are granted during the intermediate period between invention and commercialization. This scheme results in a peculiar dichotomy since the parties' intentions, or more properly the lack thereof, are identical at all points prior to the medium's commercialization.

The novel treatment described in this Comment properly balances the incentives needed by authors to create and the stimuli required for nascent media to flourish. By awarding the rights to new uses to the grantee-publisher for all contracts that preceded commercialization of the medium, short-term transaction costs are eliminated for that medium; this approach allows publishers to channel content into the new medium, helping that medium achieve viability. Perhaps more importantly, once the medium becomes commercialized, when it no longer requires subsidies, more recent contracts are no longer presumed to grant new-use rights. The incentives of authorship are maintained and society benefits from new media development. 